\title{
Non-febrile COVID-19 patients were common and often became critically ill: a retrospective multicenter cohort study
}

\author{
Yichen $\mathrm{Li}^{1+}, \mathrm{Na}$ Jiao ${ }^{1+}$, Lixin Zhu ${ }^{1 *+} \mathbb{D}$, Sijing Cheng ${ }^{1}$, Ruixin Zhu $^{2^{*}}$ and Ping Lan ${ }^{1 *}$
}

Keywords: COVID-19, SARS-CoV-2, Fever, Febrile, Critical

\section{To the Editor:}

Recent cohort studies frequently reported low rate of fever in coronavirus disease 2019 (COVID-19) patients $[1,2]$, which was in sharp contrast with previous studies that reported $>98 \%$ of patients presented fever on admission [3, 4]. Fever is a protective response for infections and an important criterion in the diagnosis of COVID-19. To understand the prevalence of fever in COVID-19 and its correlation with other symptoms and outcomes, we conducted a chart review of 252 hospitalized patients from 15 participating hospitals in Guangdong, Hubei, and Jiangxi provinces, China, from January 19 to March 6, 2020 (Table 1). Diagnosis of COVID-19 was based on positive severe acute respiratory syndrome-related coronavirus-2 (SARS-CoV-2) reverse transcription-PCR test. Our study was approved by the institutional review boards of the Sun Yat-sen University and the participating hospitals.

Demographic, clinical, laboratory, treatment, and outcome data were collected. The hospital course was reviewed for severity of disease. Critically ill patients were defined as those admitted to the ICU requiring mechanical ventilation or had a fraction of inspired oxygen $\left(\mathrm{FiO}_{2}\right)$ of at least 60\% [5]. SPSS (Statistical Package for the Social Sciences) version 24.0 software (SPSS Inc.)

\footnotetext{
* Correspondence: zhulx6@mail.sysu.edu.cn; rxzhu@tongji.edu.cn; lanping@mail.sysu.edu.cn

†Yichen Li, Na Jiao and Lixin Zhu contributed equally to this work.

${ }^{1}$ The Sixth Affiliated Hospital, Sun Yat-sen University, Guangzhou 510655, China

${ }^{2}$ Putuo People's Hospital, Department of Bioinformatics, Tongji University, Shanghai 200092, China
}

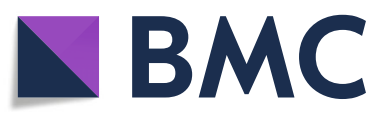

(C) The Author(s). 2020 Open Access This article is licensed under a Creative Commons Attribution 4.0 International License, which permits use, sharing, adaptation, distribution and reproduction in any medium or format, as long as you give appropriate credit to the original author(s) and the source, provide a link to the Creative Commons licence, and indicate if changes were made. The images or other third party material in this article are included in the article's Creative Commons licence, unless indicated otherwise in a credit line to the material. If material is not included in the article's Creative Commons licence and your intended use is not permitted by statutory regulation or exceeds the permitted use, you will need to obtain permission directly from the copyright holder. To view a copy of this licence, visit http://creativecommons.org/licenses/by/4.0/ The Creative Commons Public Domain Dedication waiver (http://creativecommons.org/publicdomain/zero/1.0/) applies to the data made available in this article, unless otherwise stated in a credit line to the data. was used for Mann-Whitney $U$, chi-square, and the Fisher's exact test. All statistical tests were two sided, with $p$ values of $<0.05$ considered to be statistically significant.

We found that, on admission, 197 (78\%) patients had temperatures $\geq 37.3^{\circ} \mathrm{C}, 93(37 \%)$ patients had temperatures $>38^{\circ} \mathrm{C}$, and $13(5 \%)$ patients had temperatures > $39^{\circ} \mathrm{C}$ (Table 1). We then examined the differential symptoms and outcomes between febrile $\left(\geq 37.3^{\circ} \mathrm{C}\right)$ and non-febrile $\left(<37.3^{\circ} \mathrm{C}\right)$ patients.

The most common symptoms on admission in both febrile and non-febrile patients were cough, poor appetite, and sputum production (Table 1). Smaller proportion of the non-febrile patients presented cough, poor appetite, and sputum production, compared to the febrile patients. In contrast, larger proportion of the nonfebrile patients presented cephalalgia. The negative correlation between cephalalgia and fever is intriguing. Currently, there is no evidence for SARS-CoV-2 infection in brain tissue, although ACE2 expression in neuron was observed. Perhaps inflammatory cytokines from peripheral blood caused headache [6] in COVID-19. Cephalalgia may be a useful sign for the identification of nonfebrile COVID-19, when epidemiological evidence for the infection exists.

No significant difference in any of the recorded comorbidities was observed between febrile and nonfebrile patients.

Similar high proportions of febrile (157 [80\%]) and non-febrile patients (43 [78\%]) required oxygen supplementation (Table 1), indicating that respiratory system was the most affected system for both groups of patients. 
Table 1 Demographics and clinical characteristics of COVID-19 patients on admission

\begin{tabular}{|c|c|c|c|c|}
\hline & Total $(n=252)$ & Febrile $(n=197)$ & Non-febrile $(n=55)$ & $P$ value \\
\hline \multicolumn{5}{|l|}{ Age, years } \\
\hline$\leq 29$ & $26(10 \%)$ & $16(8 \%)$ & $10(18 \%)$ & \multirow[t]{4}{*}{0.121} \\
\hline $30-49$ & $106(42 \%)$ & 85 (43\%) & $21(38 \%)$ & \\
\hline $50-69$ & $94(37 \%)$ & $73(37 \%)$ & $21(38 \%)$ & \\
\hline$\geq 70$ & $26(10 \%)$ & $23(12 \%)$ & $3(5 \%)$ & \\
\hline \multicolumn{5}{|l|}{ Sex } \\
\hline Female & $110(44 \%)$ & $82(42 \%)$ & $28(51 \%)$ & \multirow[t]{2}{*}{0.231} \\
\hline Male & $141(56 \%)$ & $114(58 \%)$ & 27 (49\%) & \\
\hline \multicolumn{5}{|l|}{ Temperature, ${ }^{\circ} \mathrm{C}$} \\
\hline$<37.3$ & $55(22 \%)$ & 0 & $55(100 \%)$ & \multirow[t]{4}{*}{$<0.001$} \\
\hline $37.3-38.0$ & $104(41 \%)$ & $104(53 \%)$ & 0 & \\
\hline $38.1-39$ & $80(32 \%)$ & 80 (41\%) & 0 & \\
\hline $39.1-41$ & $13(5 \%)$ & $13(7 \%)$ & 0 & \\
\hline \multicolumn{5}{|l|}{ Signs and symptoms } \\
\hline Cough & 177 (70\%) & $145(74 \%)$ & $32(58 \%)$ & 0.027 \\
\hline Myalgia & $42(17 \%)$ & $33(17 \%)$ & $9(16 \%)$ & 0.946 \\
\hline Cephalalgia & $22(9 \%)$ & $12(6 \%)$ & $10(18 \%)$ & 0.005 \\
\hline Sputum & $105(42 \%)$ & $92(47 \%)$ & $13(24 \%)$ & 0.002 \\
\hline Hemoptysis & $4(2 \%)$ & $4(2 \%)$ & 0 & 0.579 \\
\hline Diarrhea & $28(11 \%)$ & $23(12 \%)$ & $5(9 \%)$ & 0.590 \\
\hline Dyspnea & $35(14 \%)$ & $28(14 \%)$ & $7(13 \%)$ & 0.768 \\
\hline Poor appetite & $140(56 \%)$ & 117 (59\%) & $23(42 \%)$ & 0.020 \\
\hline \multicolumn{5}{|l|}{ Comorbidity } \\
\hline Hypertension & $48(19 \%)$ & $39(20 \%)$ & $9(16 \%)$ & 0.566 \\
\hline Diabetes & $18(7 \%)$ & $14(7 \%)$ & $4(7 \%)$ & 1.000 \\
\hline Digestive tract disease & $4(2 \%)$ & $2(1 \%)$ & $2(4 \%)$ & 0.444 \\
\hline Cardiovascular disease & $10(4 \%)$ & $8(4 \%)$ & $2(4 \%)$ & 1.000 \\
\hline Cerebrovascular disease & $3(1 \%)$ & $3(2 \%)$ & 0 & 1.000 \\
\hline Malignancy & $4(2 \%)$ & $2(1 \%)$ & $2(4 \%)$ & 0.444 \\
\hline Liver disease & $6(2 \%)$ & $3(2 \%)$ & $3(5 \%)$ & 0.234 \\
\hline Chronic lung disease & $8(3 \%)$ & $5(3 \%)$ & $3(5 \%)$ & 0.512 \\
\hline \multicolumn{5}{|l|}{ Treatments and outcomes } \\
\hline Oxygen supplementation & 200 (79\%) & 157 (80\%) & $43(78 \%)$ & 0.806 \\
\hline Mechanical ventilation & $10(4 \%)$ & $9(5 \%)$ & $1(2 \%)$ & 0.594 \\
\hline ECMO & $4(2 \%)$ & $4(2 \%)$ & 0 & 0.579 \\
\hline Critically ill & $52(21 \%)$ & 40 (20\%) & $12(22 \%)$ & 0.806 \\
\hline ARDS & $21(8 \%)$ & $17(9 \%)$ & $4(7 \%)$ & 0.963 \\
\hline ICU admission & $43(17 \%)$ & $34(17 \%)$ & $9(16 \%)$ & 0.876 \\
\hline Mortality & $6(2 \%)$ & $6(3 \%)$ & 0 & 0.344 \\
\hline
\end{tabular}

Data are median (IQR) or $n(\%) . P$ values comparing febrile and non-febrile are from Mann-Whitney $\mathrm{U}$ test, $X^{2}$ test, or Fisher's exact test, as appropriate Medical records of COVID-19 patients were accessed from Jingzhou Hospital of Traditional Chinese Medicine (61 cases), Jianli Hospital of Traditional Chinese Medicine (41 cases), Jingzhou Central Hospital (21 cases), Dongguan People's Hospital (14 cases), Jieyang People's Hospital (8 cases), Shangrao People's Hospital (12 cases), Shangrao No.2 People's Hospital (3 cases), Poyang People's Hospital (53 cases), Yugan People's Hospital (3 cases), Wuyuan People's Hospital (5 cases), Dexing People's Hospital (3 cases), Guangfeng People's Hospital (16 cases), Yushan People's Hospital (9 cases), Yanshan People's Hospital (2 cases), and Wannian People's Hospital (1 case)

ECMO extracorporeal membrane oxygenation, ARDS acute respiratory distress syndrome, ICU intensive care unit 
Among these, 17 (9\%) febrile and 4 (7\%) non-febrile patients developed acute respiratory distress syndrome (ARDS). Forty-three (17\%) febrile and 9 (16\%) nonfebrile patients were admitted to the ICU. Critical illness was similarly common in the febrile (40 patients [20\%]) and non-febrile (12 patients [22\%]) patients.

Fever promotes inflammatory reaction, which may help control viral infection leading to beneficial outcomes. However, fever-induced upregulation of the inflammatory cytokines such as IL-1, TNF, and IL-6 may contribute to cytokine storm that contributes to critical illness. These double-edged effects of fever may explain the absence of correlation between fever and the disease outcome.

Given the high proportion of non-febrile patients in COVID-19, and that $20 \%$ non-febrile patients became critically ill, heightened attention for this elusive group of patients may be required for a better containment of the pandemic. Our finding is a timely alarm for health care workers and general population that temperature monitoring alone does not identify many of the COVID19 patients.

\section{Abbreviations}

ARDS: Acute respiratory distress syndrome; COVID-19: Coronavirus disease 2019; $\mathrm{FiO}_{2}$ : Fraction of inspired oxygen; SARS-CoV-2: Severe acute respiratory syndrome-related coronavirus-2

\section{Acknowledgements}

We thank Drs. Jie Li, Guangjun Yan (Jingzhou Hospital of Traditional Chinese Medicine, China), Yunle Wan, Yifeng Zou (The Six Affiliated Hospital of Sun Yat-sen University, China), Lihan Shen (Dongguan People's Hospital, China), and Shudong Jiang (Jieyang People's Hospital, China) for assistance in the data collection.

\section{Authors' contributions}

LZ, RL, and PL conceived and designed this study. YL, NJ, SC, and LZ collected the data. All authors analyzed the data. $Y L, N J$, and $L Z$ prepared the manuscript. All authors critically revised the manuscript and approved the final version.

\section{Funding}

This study was partially supported by the National Natural Science Foundation of China 81770571 (to LZ), 81970452 (to PL), 81774152 (to RZ); the Guangzhou Science and Technology Plan Projects 201803040019 (to PL); Guangdong Province "Pearl River Talent Plan" Innovation and Entrepreneurship Team Project (2019ZT08Y464); Sun Yat-sen University 5010 project 2010012 (to PL); and the National Key Clinical Discipline of China.

\section{Availability of data and materials}

The data that support the findings of this study are available from the corresponding author upon reasonable request.

\section{Ethics approval and consent to participate}

Our study was approved by the institutional review boards of the Sun Yatsen University and the participating hospitals. The informed consent was waived because this chart review did not involve any patient tissue or interview.

\section{Consent for publication}

Not applicable.

\section{Competing interests}

All authors declare no competing interests.
Received: 20 May 2020 Accepted: 27 May 2020

Published online: 08 June 2020

\section{References}

1. Goyal P, Choi JJ, Pinheiro LC, Schenck EJ, Chen R, Jabri A, Satlin MJ, Campion TR Jr, Nahid M, Ringel JB, et al. Clinical characteristics of COVID-19 in New York City. N Engl J Med. 2020. https://doi.org/10.1056/ NEJMc2010419.

2. Richardson S, Hirsch JS, Narasimhan M, Crawford JM, McGinn T, Davidson KW, the Northwell C-RC, Barnaby DP, Becker LB, Chelico JD, et al. Presenting characteristics, comorbidities, and outcomes among 5700 patients hospitalized with COVID-19 in the New York City area. JAMA. 2020;323(20): 2052-9.

3. Wang D, Hu B, Hu C, Zhu F, Liu X, Zhang J, Wang B, Xiang H, Cheng Z, Xiong Y, et al. Clinical characteristics of 138 hospitalized patients with 2019 novel coronavirus-infected pneumonia in Wuhan, China. JAMA. 2020; 323(11):1061-9.

4. Huang C, Wang Y, Li X, Ren L, Zhao J, Hu Y, Zhang L, Fan G, Xu J, Gu X, et al. Clinical features of patients infected with 2019 novel coronavirus in Wuhan, China. Lancet. 2020;395(10223):497-506.

5. Yang $X, Y u$ Y, Xu J, Shu H, Xia J, Liu H, Wu Y, Zhang L, Yu Z, Fang M, et al. Clinical course and outcomes of critically ill patients with SARS-CoV-2 pneumonia in Wuhan, China: a single-centered, retrospective, observational study. Lancet Respir Med. 2020;8(5):475-81.

6. Zhang $X$, Burstein R, Levy D. Local action of the proinflammatory cytokines IL-1 beta and IL-6 on intracranial meningeal nociceptors. Cephalalgia. 2012; 32(1):66-72.

\section{Publisher's Note}

Springer Nature remains neutral with regard to jurisdictional claims in published maps and institutional affiliations.
Ready to submit your research? Choose BMC and benefit from:
- fast, convenient online submission
- thorough peer review by experienced researchers in your field
- rapid publication on acceptance
- support for research data, including large and complex data types
- gold Open Access which fosters wider collaboration and increased citations
- maximum visibility for your research: over $100 \mathrm{M}$ website views per year
At BMC, research is always in progress.
Learn more biomedcentral.com/submission 